
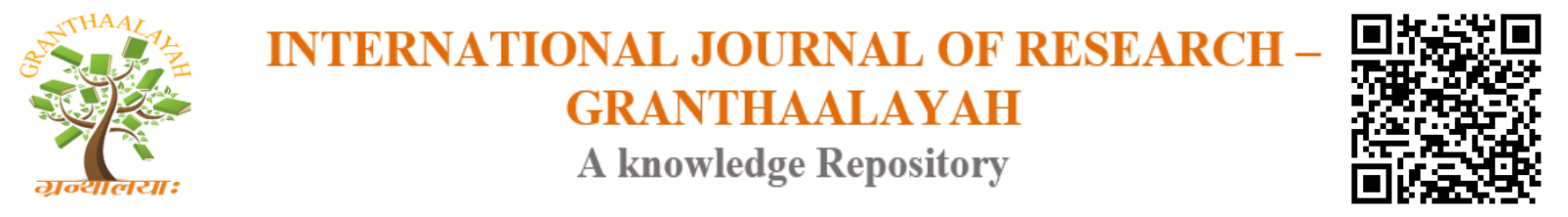

Social

\title{
DUST EXPOSURE AND RESPIRATORY HEALTH SYMPTOMS AMONG WORKERS IN SMALL SCALE SUNFLOWER OIL INDUSTRY IN SINGIDA TANZANIA
}

\author{
Venance Buliga ${ }^{1}$, Larama MB Rongo ${ }^{* 2}$, Simon HD Mamuya ${ }^{3}$ \\ ${ }^{1} \mathrm{MSc}$ EOH, Department of Environmental and Occupational Health, Muhimbili University of \\ Health and Social Sciences, Tanzania \\ ${ }^{* 2,} \mathrm{PhD}$, Department of Environmental and Occupational Health, Muhimbili University of \\ Health and Social Sciences, Tanzania
}

\begin{abstract}
Background: Small scale sunflower oil industries are industries which extract oil from sunflower seed. Apart from its contribution to the economic development of the nation, during extraction process much dust concentration produced and respiratory symptoms are unknown. The aim of study was to assess dust exposure and associated respiratory health symptoms among small scale sunflower oil industries workers in Singida Tanzania.

Methods: A cross sectional study was conducted and 233 participants were interviewed using a modified American Thoracic Society questionnaire to assess the respiratory health symptoms. A Side Kick Casella Pump was used to collect respirable dust from a sub sample of 66 workers from the sieving section.

Results: Respirable dust exposure levels for mean, and Geometrical mean was $10.45 \mathrm{mg} / \mathrm{m} 3$ (SD 13.90) and $\mathrm{GM}=5.25 \mathrm{mg} / \mathrm{m} 3$ (GSD 0.51) respectively, and $46 \%$ of the dust samples ( $=66$ ) were above the TLV of $5 \mathrm{mg} / \mathrm{m} 3$. Logistic regression analysis between measured dust and respiratory symptoms found to be statistically significant. Higher prevalence of respiratory health symptoms were seen in those with cough (33\%), cough with phlegm (46.8\%) and wheezy (41.6\%).
\end{abstract}

Conclusion: The study concludes that, respiratory symptoms were high and dust exposure was above recommended levels of $5 \mathrm{mg} / \mathrm{m} 3$. We recommend use of appropriate RPE.

Keywords: Small Scale Sunflower Workers; Sunflower Dust; Respiratory Symptoms; Tanzania.

Cite This Article: Venance Buliga, Larama MB Rongo, and Simon HD Mamuya. (2017). "DUST EXPOSURE AND RESPIRATORY HEALTH SYMPTOMS AMONG WORKERS IN SMALL SCALE SUNFLOWER OIL INDUSTRY IN SINGIDA TANZANIA.” International Journal of Research - Granthaalayah, 5(12), 452-464. 10.29121/granthaalayah.v5.i12.2017.531. 


\section{Introduction}

Small scale sunflower oil industries are industries which extract oil from sunflower seed. This crop (Helianthus annuus lenticularis) is one of the most important oilseed crops in Tanzania and other many countries for industrial purposes. Current statistical data in Tanzania on sunflower shows that local production of both factory and home extracted oils contributes to about $40 \%$ of the national cooking oil requirement and its gaining popularity with the remaining $60 \%$ being imported (Strategy, 2008)

Apart from its contribution to the economic development of the nation, during extraction process much dust and other debris are produced, which are harmful to human health. Studies show that many occupational diseases which cause death arise due to workers exposure to dust or particulates at work in many different working conditions depending on the nature of work they are performing ((Tim Driscoll, Steenland K, Nelson, 2005) and many of these workers develop respiratory complications because of the lack of knowledge of potential hazards posed by industrial dust at their working environment(Michael D. Shaw, 2004). The study shows that, as the economic activities increases also the occupational death and injuries increases at workplaces (Mrema, Ngowi, \& Mamuya, 2015).

Workers working in small and large scale industries have been exposed to different types of dust during production process. Different cases of respiratory problems have been reported which are associated with occupational dust exposure and the magnitude of problems influenced by dust itself and duration of workers working in dusty conditions (Mohammadien, Hussein, \& ElSokkary, 2013). Furthermore different studies have shown relationship between dust exposures level and respiratory health effect of workers working in grain and flour mills and its prevalence was reported to be higher (Ghosh, Gangopadhyay, \& Das, 2014).Worldwide occupational exposure to particulates are the key factors for death and disability due to its major effects, the study shows that about 1.6 million of deaths are caused by asthma,3.8million deaths are caused by Chronic Obstructive pulmonary diseases (COPD) and 1.3million deaths are caused by pneumoconiosis each year(Tim Driscoll, Steenland K, Nelson DI, 2005),(Tim Driscoll, Steenland, et al, 2004).

Study done on Occupational chronic obstructive pulmonary diseases concluded that, $15 \%$ of COPD is caused by occupational exposure of dusts, gas, fumes and vapour(Pedersen, Schlünssen, Sigsgaard, Cs, \& Viskum, 2014).

In Least Developing Country (LDC) health and safety are not given much attention and millions of workers are victims of work related diseases and illness because of much higher exposure to hazardous working environment and unable to report the actual problems because of the fear for loosing job (Rabiul, 2001).

Sunflower oil mill is the growing industries which employ many people in Tanzania and workers are protected by different Acts like Occupational Health and Safety (OHS) Act of 2003, Workers compensation Act of 2008, Environmental Management (EM) Act of 2004 and Public Health Act of 2007 on the issue of Health and Safety hazard. 
However workers protection against dust and other occupational hazards in a major challenge in Tanzania, particularly small scale industries which have been shown to be neglected, unregulated and left without any form of preventive, protective or health promotion action(L. M. Rongo., G.Msamanga., et al 2004),(Buhlebenkosi, Sibanda, et al, 2013).

In Tanzania there is limited information on dust exposure concentration and associated respiratory health symptoms among small scale sunflower oil industry workers.

Hence, this study aimed to determined concentration of dust exposure and associated respiratory health symptoms among small scale sunflower oil industries workers in Singida Tanzania.

\section{Materials and Methods}

\subsection{Study Population and Setting}

A cross sectional study design was conducted in Singida Tanzania among small-scale sunflower oil industries between May and June 2017.

The study population involved workers working in small scale sunflower oil industries for 12 months and above in the study area.

\subsection{Sample Size Estimation and Sampling Technique}

We obtained a sample of 233 workers using a single standard proportion formula Kirkwood (Kirkwood, 2003) Since no national data on the prevalence of respiratory health symptoms in small scale sunflower oil mill industry, prevalence (P) of $27 \%$ on coffee industries workers study at Kilimanjaro -Tanzania (Sakwari, Bråtveit, Mamuya, \& Moen, 2011) were used for the purpose of this study.

A multistage sampling technique was used to select study participants from the study area. At first stage, simple random sampling was used to select three wards out of sixteen wards in Singida Municipality. At the second stage, simple random sampling was used to select ten small scale industries each from the selected three wards making a total of thirty (30) small scale industries. Thereafter from thirty (30) industries, a simple random sampling was used to select five (5) industries to be included on study and all workers who were eligible and had worked for more than one year or equal were selected until a total number of 233 study participants obtained.

\subsection{Sample Size for Respirable Dust}

Selection of workers to be sampled for respirable dust were selected from 30 small scale industries operating in the area, a systematic randomly sampling was used to select 7 representative small scale industries from which a NIOSH guideline was used to select Homogeneous Exposure Group from a job section who perform similar task different from other workers. Given the number of workers in small scale industries from the owners, six industries with $\mathrm{N}=6$ and one industry with $\mathrm{N}=7$ were included, and for ensuring validity of study, 
repeated sample was carried out where by half of the participants were involved at each industries $(6 \times 3)$ and $(1 \times 4)$ by randomly sampling. Therefore total of 66 study participants for respirable dust exposure assessment as per NIOSH guideline were included (Leidel A. et al NIOSH, 1997). Also one cassette with filter were taken after each 10 samples as dummy for ensuring if there is weight gain or loss for filters which will be computing during calculation of dust concentration.

\subsection{Exposure Assessment}

Personal dust exposure was sampled throughout the work shift for 8 hours in the breathing zone of participants who agreed to participate in the study. Sampling was done by using Side Kick Casella (SKC) pumps operated at a flow rate of $2.0 \mathrm{~L} /$ minutes attached to closed cassettes fitted with $37 \mathrm{~mm}$ of Poly Vinyl Chloride (PVC) filters of 0.5 micrometer (um) pore size. Humidity in the filters was removed using desiccators for 24 hours in the conditioned room before and after field work. Also the filters were weighted by a Mettler Toledo weighing balance before and after sampling at MUHAS Laboratory. Thereafter the cassettes with filter taken to the field for dust sampling, and the sampling time varied from 300 to 480 minutes.

Dust concentration for each exposed worker was calculated and means dust concentration was obtained. The results were compared to the standard, TLV of $5 \mathrm{mg} / \mathrm{m} 3$.

For field information control, dust sampler was labeled each day of dust sampling. Dust collection form was used to collect information such as name, date, pump number, filter number, total time sampled and pre-and post-calibration.

\subsection{Assessment of Reported Respiratory Health Symptoms}

Questionnaire guided to assess respiratory health symptoms among workers. The questions were adopted from a standardized questionnaire for assessing respiratory symptoms from the American Thoracic Society (ATS). In Tanzania, the questionnaire was adopted, modified and used by Mamuya et al., (2007) on their study to assess respiratory symptoms among coal mines workers, and the results were successful. The questions were modified to suit the Tanzanian environment. The modified questions were translated to Swahili and then back to English by different person. The back translated questionnaire was then compared to the original English version and corrections were made in the translated questionnaire. Interviews were conducted in Swahili language, and observation checklists were used to assess the use of personal respiratory protective equipment at each industry.

\subsection{Data Collection}

Data was collected using a structured interview questionnaire and observation checklist, which was constructed in English and translated into Swahili language and back to English, comprise closed ended questions, with predefined answers. The questionnaires were piloted in a small sample of the 15 workers in small scale sunflower oil industries in Dodoma region. Pretesting of the study helped to review the questions and to improve those which seemed to be difficult to the 
respondents, but these data were excluded in the analysis. Information was collected based on demographic, occupational history and respiratory health symptoms.

On the days of data collection prior to interview, the research team introduced themselves and the purpose of the research was outlined to them.

The respondents who were accessible, meeting criteria and willing to participate in the study were provided the consent form. The interview was carried out during working day; thereafter respondents were required to wear the dust sampling pump. Machine was positioned at each respiratory zone (within $30 \mathrm{~cm}$ from the nose) of respondents for 8 working hours and thereafter machines were removed for laboratory analysis. To ensure confidentiality researchers were informed the participants not to write their names instead the number could be written on the questionnaires.

\subsection{Statistical Analysis}

Statistical Package for Social Sciences (SPSS) version 20 was used to process the data. The data entered in the computer was cleaned by running frequency percentages. Cleaned data for descriptive analysis were analyzed where frequency distribution and percentages were presented in bar chart, pie chart and cross tabulation tables. Chi - square tests were used to assess the statistical significance of the association between categorical variables. Ficher's exact test was used when any expected value was less than 5. P value of less than 0.05 was considered statistically significant. Logistic regression analysis was employed for controlling of confounders such as age, smoking, previous dust exposure, duration of employment.

\subsection{Ethical Clearance}

Ethical approval was obtained from Muhimbili University of Health and Allied Sciences, Directorate of Research ethics and publication committee with reference number MU/PGS/SAEC/Vol.IX/85

\section{Results and Discussions}

In this study all 233 participants agreed to be interviewed and respirable dust was obtained from 66 workers.

\subsection{Socio Demographic Study}

Table 1: Socio demographic characteristics of the workers $(n=233)$

\begin{tabular}{|l|l|l|}
\hline Characters & & $\mathbf{N}(\%)$ \\
\hline Age (years) & $\leq 25$ & $52(22.3)$ \\
\hline & $26-35$ & $100(42.9)$ \\
\hline & $36-45$ & $52(22.3)$ \\
\hline & $\geq 46$ & $29(12.5)$ \\
\hline Sex & Male & $107(45.9)$ \\
\hline
\end{tabular}




\begin{tabular}{|l|l|l|}
\hline & Female & $126(54.1)$ \\
\hline Marital status & Single & $79(33.9)$ \\
\hline & Married & $130(55.8)$ \\
\hline & Divorced & $16(6.9)$ \\
\hline & Widow & $8(3.4)$ \\
\hline Level of education & Informal education & $20(8.6)$ \\
\hline & Primary education & $192(82.4)$ \\
\hline & Secondary education & $18(7.7)$ \\
\hline & Tertiary education & $3(1.3)$ \\
\hline Duration of employment(years) & $1-10$ & $211(90.6)$ \\
\hline & $\geq 11$ & $22(9.4)$ \\
\hline
\end{tabular}

\subsection{Respiratory Health Symptoms}

Table 2: Proportions of respiratory health symptoms among workers $(\mathrm{n}=233)$

\begin{tabular}{|l|l|l|}
\hline Symptoms & Frequency(n) & Percent (\%) \\
\hline Cough & & \\
\hline Usually cough & 77 & 33 \\
\hline On getting up or first thing in the morning & 77 & 33 \\
\hline During day or night & 121 & 51.9 \\
\hline 5 to 6 times a day & 71 & 30.5 \\
\hline 4 days more out of a week & 26 & 11.2 \\
\hline On most days for as much 3 months each years & 34 & 14.6 \\
\hline Phlegm & & \\
\hline Bring phlegm from chest & 109 & 46.8 \\
\hline On getting up or first thing in the morning & 56 & 24 \\
\hline Twice a day, or four days more out of a week? & 83 & 35.6 \\
\hline Wheezy & & \\
\hline Sound wheezy & 97 & 41.6 \\
\hline Wheezy when cold & 17 & 7.3 \\
\hline Chest tightness & & \\
\hline Chest feel tight & 23 & 9.9 \\
\hline Chronic lung condition & & \\
\hline Asthma & 3 & 1.3 \\
\hline Emphysema & 6 & 2.6 \\
\hline
\end{tabular}

\subsection{Use of Respiratory Protective Equipment (RPE)}

The uses of respiratory protective equipment were higher among $67.8 \%$ of participants while $32.2 \%$ reported not using any form of respiratory equipment. Among those responded using respiratory equipment $55.8 \%$ of participants use a piece of clothes as their RPE and $14.6 \%$ use both a piece of clothes and modern mask to cover their mouth and nose during the 8 hours of working and the equipment were not classified according to the quality of protection. 


\subsection{Sunflower Dust Exposure ( $\mathbf{N}=66)$}

The study showed that, the mean personal dust exposure level is $10.45 \mathrm{mg} / \mathrm{m} 3$ (SD 13.90) for workers in small scale oil industries included in the study for a mean sampling time of 8 hours. The Geometric mean (GM) was $5.24 \mathrm{mg} / \mathrm{m} 3$ (GSD 0.50). About $46 \%$ of the workers were exposed to dust above the acceptable recommended limit of $5 \mathrm{mg} / \mathrm{m} 3$ of respirable dust of American Conference of Governmental Industrial Hygienist (ACGIH).

\subsection{Logistic Regression of Sunflower Dust Concentration and Respiratory Health Symptoms}

Table 3: Show Logistic regression of Sunflower dust and Respiratory health symptoms $(\mathrm{n}=66)$

\begin{tabular}{|l|c|r|r|l|l|}
\hline & B & SE & OR & 95\% CI & P-value \\
\hline DUST CONCENTRATION & & & & & \\
\hline Cough & 0.943 & 0.218 & 2.567 & $1.673-3.937$ & $0.000^{*}$ \\
\hline Phlegm & 0.234 & 0.164 & 1.264 & $0.917-1.742$ & 0.153 \\
\hline Wheezing & 0.555 & 0.180 & 1.742 & $1.223-2.481$ & $0.002^{*}$ \\
\hline Difficult breathing & 1.761 & 0.357 & 5.819 & $2.891-11.714$ & $0.000^{*}$ \\
\hline Breathlessness & 1.761 & 0.357 & 5.819 & $2.891-11.714$ & $0.000^{*}$ \\
\hline
\end{tabular}

Odds ratio (OR), 95\%, $\mathrm{P}<0.05$, Standard error $(\mathrm{SE})$

\subsection{Logistic Regression of Risk Factors of Respiratory Health Symptoms}

Table 4: Logistic regression of risk factors of respiratory health symptoms $(n=233)$

\begin{tabular}{|l|l|l|l|l|l|}
\hline Factor & $\boldsymbol{\beta}$ & SE & OR & 95\% CI & p-value \\
\hline COUGH & & & & & \\
\hline Age & 0.016 & 0.004 & 1.016 & $1.009-1.024$ & $0.000^{*}$ \\
\hline Employment duration & 0.647 & 0.127 & 1.909 & $1.490-2.447$ & $0.000^{*}$ \\
\hline Smoking cigarette & 0.386 & 0.074 & 1.471 & $1.272-1.701$ & $0.000^{*}$ \\
\hline Previous dust job & 0.377 & 0.074 & 1.457 & $1.260-1.686$ & $0.000^{*}$ \\
\hline PHLEGM & & & & & \\
\hline Age & 0.001 & 0.004 & 1.001 & $0.994-1.008$ & 0.792 \\
\hline Employment duration & 0.100 & 0.116 & 1.106 & $0.881-1.388$ & 0.386 \\
\hline Smoking cigarette & 0.106 & 0.070 & 1.111 & $0.970-1.274$ & 0.129 \\
\hline Previous dust job & 0.041 & 0.070 & 1.042 & $0.909-1.194$ & 0.555 \\
\hline WHEEZING & & & & & \\
\hline Age & 0.008 & 0.004 & 1.008 & $1.001-1.016$ & $0.024^{*}$ \\
\hline Employment duration & 0.333 & 0.119 & 1.396 & $1.106-1.761$ & $0.005^{*}$ \\
\hline Smoking cigarette & 0.209 & 0.071 & 1.232 & $1.073-1.415$ & $0.003^{*}$ \\
\hline Previous dust job & 0.149 & 0.070 & 1.160 & $1.011-1.332$ & $0.035^{*}$ \\
\hline DIFFICULT BREATHING & & & & & \\
\hline Age & 0.070 & 0.007 & 1.073 & $1.057-1.089$ & $0.000^{*}$ \\
\hline Employment duration & 2.085 & 0.213 & 8.044 & $5.300-12.209$ & $0.000^{*}$ \\
\hline Smoking cigarette & 1.169 & 0.119 & 3.217 & $2.547-4.064$ & $0.000^{*}$ \\
\hline
\end{tabular}


DOI: 10.5281/zenodo.1146334

\begin{tabular}{|l|l|l|l|l|l|}
\hline Previous dust job & 1.201 & 0.123 & 3.322 & $2.613-4.224$ & $0.000^{*}$ \\
\hline BREATHLESSNESS & & & & & \\
\hline Age & 0.069 & 0.007 & 1.071 & $1.056-1.086$ & $0.000^{*}$ \\
\hline Employment duration & 2.040 & 0.209 & 7.694 & $5.109-11.587$ & $0.000^{*}$ \\
\hline Smoking cigarette & 1.183 & 0.121 & 3.264 & $2.577-4.134$ & $0.000^{*}$ \\
\hline Previous dust job & 1.201 & 0.123 & 3.322 & $2.613-4.224$ & $0.000^{*}$ \\
\hline
\end{tabular}

Odd ratio (OR), 95\%, $\mathrm{p}<0.05$, Standard error $(\mathrm{SE})$.

\section{Discussion}

The general objective of the present study was to assess the dust exposure and associated respiratory health symptoms among workers in small scale sunflower oil industry in Singida Tanzania, with the purpose to develop strategies for control of sunflower dust exposure and prevent respiratory health symptoms such as (cough, phlegm, wheezing, chest tightness and breathlessness) to workers. One of the reasons for the assessment of sunflower dust exposure in Singida was about the risk of respirable dust to human health. The findings of this study could lay foundation for the development of strategies to prevent and control sunflower dust exposure to small scale sunflower oil industry not only in Tanzania but also in other African countries using the same technology.

\subsection{Respiratory Health Symptoms Among Workers in Sunflower Oil Industries}

This study shows low respiratory symptoms prevalence ranging from $9 \%$ to $47 \%$ similar to the findings shown by (Ghasemkhani., M.Kumashiro M. 2006),(Shamssain, 1995) among workers in industries of Tehran Iran and workers in Umtata Southern Africa respectively.

These results are inconsistent with those of (Mohammadien HA., Hussein MT., El-Sokkary RT., 2013) who study on the effect of exposure to flour dust on respiratory symptoms and pulmonary function of mill workers in Sohag Governorate, Southern Egypt and showed higher prevalent of respiratory health symptoms ranging from $7 \%$ to $73 \%$. The observed difference could perhaps be explained by setting in which the study was done.

This study also showed that, there is no association of employment and respiratory symptoms. This could perhaps be explained by the health workers effect; workers who are already serious sick are exempted from work.

\subsection{Dust Exposure}

The study showed that $46 \%$ of samples exceeded permitted dust levels according to the limit set by ACGIH. The results are different from the study of (Zuskin, Skuric, \& Kanceljak, 1988) Respiratory symptoms and ventilator capacity in soy bean workers in United State which shows, dust exposure for respirable dust exceed the recommended limit which is low compare to sunflower dust exposure. 
The observed difference could be due to the study setting, but also it could be due to measures used for dust control, large industry might have used engineering measure for dust control as compared to small scale.

The results are also different to the findings shown by (Nelson, Easter, Jimmy.,et al, 2015), (Bhatti P.,Newcomer L.,Onstad L., 2010) among wood dust in United State, wood dust in Nigeria showed higher $86.4 \%$ of participants exposed to wood dust and $20 \mathrm{mg} / \mathrm{m} 3$ found in compressed air cleaning respectively. This may be because of small sample size in our study.

\subsection{Use of Respiratory Protective Equipment}

This study shows that, the increase of respiratory symptoms is due to the dust. Higher use of PPE was associated with less symptoms, this was due to the fact that the higher percent of workers in small scale sunflower oil industries found using the RPE which are not classified or recommended for the quality of protection. Only few workers observed wearing both piece of clothes and the modern mask at the same times when exposing to higher levels of dust. Even if the workers provided with modern mask were not comfortable with the quality standard of the RPE.

These findings are similar to the study done in Nigeria on occupational exposure to wood dust, where workers did not use personal protective equipment such as respiratory protective equipment (Nelson O., Easter CO., Jimmy CE, 2015) This is also revealed to the study done in Tanzania in wood dust where only $6.5 \%$ of workers were found using a piece of clothes as the RPE for dust control and which is not effective for dust control (L. M. B. Rongo., G.Msamnga., et al. 2005).

Also it was observed that, $55.8 \%$ of the participants wearing a piece of clothes as the RPE and $32 \%$ of the participants not using any form of RPE. This is similar to the study done in Tanzania on respiratory symptoms among street sweepers which show $61.8 \%$ of participants wearing piece of cloth and only $47.1 \%$ of the participants not wearing RPE and concluded that the lack of RPE lead to the increase of respiratory symptoms (Stambuli, 2012).

These finding are in line with the study done on dust exposure during small scale mining in Tanzania which showed that working without using RPE, workers are exposed to high risk of developing respiratory symptoms (Mohammadien HA., Hussein MT. et al, 2013).

Following the results shown above, workers in small scale industries found in Singida were not using RPE as recommended by OSHA the reason could be provided or inadequate provisional of RPE from their employers.

\subsection{Predictor of Respiratory Health Symptoms}

This study showed that those smoking cigarette were more likely to have cough, phlegm and wheezing, and previous dusty job are three times more likely to have difficulty breathing and breathlessness as the respiratory health symptoms. This study support the finding of organic dust 
study showing that cigarette smoking was the contributory factor of respiratory health symptoms (Laakkonen, 2008).

Also the finding was similar to the study done on respiratory impairment in coffee factory workers in Papua New Ginea and exposure to wood dust to sawmill workers in Nigeria which show that, smoking and previous dusty exposure are the predictor of respiratory health symptoms(Smith, Brott, \& Koki, 1985), (Tobin Ea., Ediagbonya Tf, Okojie Oh, et al, 2016) respectively.

\section{Conclusions and Recommendations}

Study shows that workers in small scale sunflower oil industry are exposed to respirable dust which is higher than the recommended TLV. These effects can be reduced by proper dust control measures. The results indicate that the higher proportion of workers in small scale sunflower oil industries found using clothes and linen as the RPE which are for protection.

\section{Recommendations}

1) Frequently Spirometry test could be conducted to determine the effect of lung function.

2) Workers working in sunflower oil industry are exposed to higher dust level, therefore they should prevent themselves on cigarette smoking alone increases the respiratory health symptoms.

3) Engineering controls to reduce dust exposure at workplace should be applied as the first measure of dust control.

4) Workers should use recommended RPE because of dust levels of dust exposure.

\section{Acknowledgements}

My special thanks to Occupational Safety and Health Authority (OSHA) -Tanzania and NORHED for their financial support which enables the study to be completed.

Thanks to my research assistant Mr. Eliapenda Kapinda from department of physiology at Muhimbili University of health and Allied Sciences for his great job and dedication during data collection. My gratitude to all sunflower oil industry workers participated in this study.

\section{References}

[1] Atis, S., Tutluoglu, B., Sahin, K., Yaman, M., Kucukusta, AR., \& Oktay, I. (2002). "SENSITIZATION TO SUNFLOWER POLLEN AND LUNG FUNCTIONS IN SUNFLOWER PROCESSING WORKERS". Allergy, 57(July 2000), 35-39.

[2] Bhatti, P., Newcomer, L., Onstad, L., Teschke, K., Camp, J., Morgan, M., \& Vaughan, T. L. (2010). "WOOD DUST EXPOSURE AND RISK OF LUNG CANCER". Occupational Environmental Medicine, 68, 599-604. http://doi.org/10.1136/oem.2010.060004

[3] Buhlebenkosi, F., Sibanda, N., Chaurura, P., \& Chiwira, O. (2013). "OCCUPATIONAL SAFETY IN THE URBAN INFORMAL SECTOR OF GABORONE, BOTSWANA: A SITUATIONAL ANALYSIS". International Journal of Scientific \& Technology Research, 2(12), 293-297. 
[4] Driscoll, T., Steenland, K., Nelson, D. I., \& Leigh, J. (2004). "OCCUPATIONAL AIRBORNE PARTICULATES": Assessing the environmental burden of disease at national and local levels. Environmental Burden of Disease Series, (7).

[5] Driscoll, T. Steenland,K.,Nelson, D.I. (2005). "THE GLOBAL BURDEN OF NON MALIGNANT RESPIRATORY DISEASE DUE TO OCCUPATIONAL AIRBORNE EXPOSURE".Retrieved from http://www.who.int/quantifying_ehimpacts/global/4airbornexposure

[6] Ea, Tobin. Tf, Ediagbonya., Oh, Okojie., \& Da, A. (2016). "POLLUTION EFFECTS \& CONTROL OCCUPATIONAL EXPOSURE TO WOOD DUST AND RESPIRATORY HEALTH STATUS OF SAWMILL WORKERS IN SOUTH-SOUTH NIGERIA". J Polutt Eff Cont, 4(1), 4-9. http://doi.org/10.4172/2375-4397.1000154

[7] Ernst, P., Dales, R. E., Nunes, F., \& Becklake, M. R. (1989). "RELATION OF AIRWAY RESPONSIVENESS TO DURATION OF WORK IN A DUSTY ENVIRONMENT". Thorax, 215(November 1988), 116-120.

[8] Ghasemkhani., M., Kumashiro., M., Rezaei., M., Anvari., A. R., Mazloumi., A., \& Sadeghipour, H. R. (2006). "PREVALENCE OF RESPIRATORY SYMPTOMS AMONG WORKERS IN INDUSTRIES OF SOUTH TEHRAN, IRAN. INDUSTRIAL HEALTH", 44, 218-224. http://doi.org/10.2486/indhealth.44.218

[9] Ghosh, T., Gangopadhyay, S., \& Das, B. (2014). "PREVALENCE OF RESPIRATORY SYMPTOMS AND DISORDERS AMONG RICE MILL WORKERS IN INDIA". Environmental Health and Preventive Medicine, 19(3), 226-233. http://doi.org/10.1007/s12199014-0384-8

[10] Kirkwood, B. \&Sterne J. A. (2003). Essential Medical Statistics 2nd ed: Blackwell Science, Oxford. Medical statistics.

[11] Laakkonen, A. (2008). "OCCUPATIONAL EXPOSURE TO ORGANIC DUSTS AND CANCER AMONG FINNISH WORKERS: SPECIAL EMPHASIS ON THE FOOD INDUSTRY AND AGRICULTURE". Finish institute of occupational health, Finland.

[12] Leidel A. Nelson.,Kenneth A. Busch., Jeremiah R.Lynch., NIOSH. (1997). "OCCUPATIONAL EXPOSURE SAMPLING STRATEGY MANUA"L.

[13] Michael D. Shaw. (2004). "RESPIRATORY DISEASES AND THEIR PREVENTION": A look at Industrial Dust and ITS control. Retrieved from https://www.gasdetection.com

[14] Mihalas, L. S. (1999). "AN APPROACH TO THE DIAGNOSIS OF OCCUPATIONAL ASTHMA". Annals of Allergy, Asthma and Immunology, 83(6), 577-582. http://doi.org/10.1016/S1081-1206(10)62875-X

[15] Mohammadien, H. A., Hussein, M. T., \& El-Sokkary, R. T. (2013). "EFFECTS OF EXPOSURE TO FLOUR DUST ON RESPIRATORY SYMPTOMS AND PULMONARY FUNCTION OF MILL WORKERS". Egyptian Journal of Chest Diseases and Tuberculosis, 62(4), 745-753. http://doi.org/10.1016/j.ejcdt.2013.09.007

[16] Mrema, E. J., Ngowi, A. V., \& Mamuya, S. H. D. (2015). "STATUS OF OCCUPATIONAL HEALTH AND SAFETY AND RELATED CHALLENGES IN EXPANDING ECONOMY OF TANZANIA". Annals of Global Health, 81(4), 538-547. http://doi.org/10.1016/j.aogh.2015.08.021

[17] Nelson, O., Easter, C. O., Jimmy, Schlunssen T,. Siggaard E. (2015). "OCCUPATIONAL EXPOSURE TO WOOD DUST IN CALABAR MUNICIPALITY, CROSS RIVER STATE, NIGERIA". International Journal of Science and Research, 4(5), 1414-1420.

[18] Pedersen, Schlünssen, V., Sigsgaard, T., Cs, U., \& Viskum, S. (2014). "SYSTEMATIC LITERATURE REVIEW OCCUPATIONAL CHRONIC OBSTRUCTIVE PULMONARY DISEASE: A SYSTEMATIC LITERATURE REVIEW". Scandinavian Journal of Work, Environment and Health, 40(1), 19-35. http://doi.org/10.5271/sjweh.3400

[19] Rabiul, M. (2001). "OCCUPATIONAL NEGLECT HEALTH AND SAFETY IN THE LEAST DEVELOPED COUNTRIES - A SIMPLE CASE OF OPPORTUNITIES FOR COMPETENCE 
DEVELOPMENTS ARE THE COMMON FEATURES OF UNSAFE BEHAVIOUR AND POOR HEALTH" 26-27). Physically demanding jobs in a hazardous workplace wi. Epidemiology Journal, (2), 74-80.

[20] Rongo, L.M.B., G.Msamanga. I.Burstyn.,Igor Barten.,Francoise Dolmans, Wil Mv Heederik.,Dick. (2005). "QUALITATIVE METHOD FOR ASSESSING DUST EXPOSURE IN SMALL-SCALE WOOD INDUSTRIES INTHE INFORMAL SECTOR". East African Journal of Public Health, 2(1).

[21] Rongo, L. M., Msamanga, G. I., Burstyn, I., Barten, F., Dolmans, W. M., \& Heederik, D. (2004). "EXPOSURE TO WOOD DUST AND ENDOTOXIN IN SMALL-SCALE WOOD INDUSTRIES IN TANZANIA". Journal of Exposure Analysis and Environmental Epidemiology, 14, 544-550. http://doi.org/10.1038/sj.jea.7500375

[22] Sakwari, G., Bråtveit, M., Mamuya, S. H., \& Moen, B. E. (2011). "DUST EXPOSURE AND CHRONIC RESPIRATORY SYMPTOMS AMONG COFFEE CURING WORKERS IN KILIMANJARO: A CROSS SECTIONAL STUDY". BMC Pulmonary Medicine, 11(1), 54. http://doi.org/10.1186/1471-2466-11-54

[23] Shamssain, M. H. (1995). "RESPIRATORY SYMPTOMS AND PULMONARY FUNCTION IN FLOUR PROCESSING WORKERS IN THE BAKING INDUSTRY". American Journal of Industrial Medicine, 27(3), 359-365. http://doi.org/10.1002/ajim.4700270305

[24] Smith, D., Brott, K., \& Koki, G. (1985). "RESPIRATORY IMPAIRMENT OF COFFEE FACTORY WORKERS IN THE ASARO VALLEY OF PAPUA NEW GUINEA". British Journal of Industrial Medicine, 42(7), 495-498. http://doi.org/10.1136/oem.42.7.495

[25] Strategy, M. D. (2008). "SUNFLOWER SECTOR". Rural Livelihood Development Company, www.rldp.org/downloads/sunflower_strategy.pfd, accessed on 2018 - 01-08,

[26] Vega, F. (1998). "OCCUPATIONAL ASTHMA CAUSED HY SUNFLOWER-SEED DUST". Allergy Net, $0-2$.

[27] Zuskin, E., Kanceljak, B., \& Schachter, E. N. (1992). "IMMUNOLOGICAL AND RESPIRATORY CHANGES IN ANIMAL FOOD PROCESSING WORKERS". American Journal of Industrial Medicine, 191, 177-191.

[28] Zuskin, E., Skuric, Z., \& Kanceljak, B. (1988). "RESPIRATORY SYMPTOMS AND VENTILATORY CAPACITY IN SOYA BEAN WORKERS". American Journal of Industrial Medicine, 165, 157-165.

*Corresponding author.

E-mail address: rongolmb@gmail.com 


\section{Appendices}

\section{MUHIMBILI UNIVERSITY OF HEALTH AND ALLIED SCIENCES OFFICE OF THE DIRECTOR OF POSTGRADUATE STUDIES}

P.O. Box 65001

DAR ES SALAAM

TANZANLA

Web: www.mulas.ac.12
Tel G/Line: $+255-22-2150302 / 6$ Ext 1015

Direct Line: $+255-22-2151378$

Telefax: $+255-22-2150465$

E-mail: dnges amuhas ac.17

Ref. No. MU/PGS/SAEC/NoL. IX/85

$3^{\text {nt April, } 2017}$

Venance Buliga

MSc Environmental and Occupational Health, MUHAS.

RE: APPROVAL OF ETHICAL CLEARANCE FOR A STUDY TITLED "ASSESSMENT OF DUST EXPOSURE AND ASSOCIATED RESPIRATORY HEALTH SYMPTOMS AMONG WORKERS IN SMALL SCALE SUNFLOWER OIL INDUSTRY SINGIDA TANZANIA."

Reference is made to the above heading.

I am pleased to inform you that, the Chairman has, on behalf of the Senate, approved ethical clearance for the above-mentioned study. Henoc you may proceed with the planned study.

The ethical clearance is valid for one year only, from $4^{\text {th }} \mathrm{April}, 2017$ to $3^{\text {te }}$ April, 2018. In case you do not complete data analysis and dissertation report writing by $3^{\text {th }}$ April 2018, you will have to apply for renewal of ethical clearance prior to the expiry date.

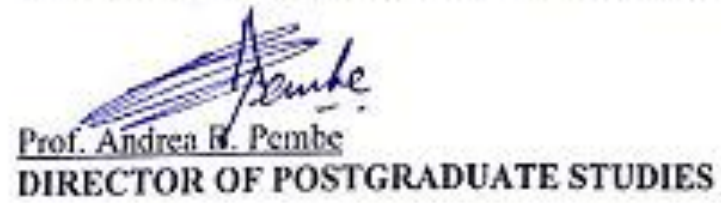

ce: Director of Research and Publication

ce: Dean, School of Public Health and Social Sciences 